RESEARCHPAPER

\title{
Some studies on post-harvest pathogens of banana from Gorakhpur(U.P.)
}

\author{
ARADHANA PAL, R.P. SINGH, POOJA SINGH AND N.N. TRIPATHI \\ Department of Botany, Deen Dayal Upadhyay Gorakhpur University, GORAKHPUR (U.P.) INDIA \\ Email : pooja.ddu@gmail.com
}

Article Info : Received : 20.06.2017; Revised : 06.08.2017; Accepted : 03.09.2017

Present investigation was conducted during November 2014 to October 2015 in Gorakhpur district (U.P.) for storage diseases of banana. The eight fruit markets were visited for survey and sampling of banana. During survey, maximum disease incidence was found during July to October from Bargadwa fruit market while minimum disease incidence was found in Raptinagar between November to February; crown rot, Anthracnose and finger rot diseases were found to be dominant diseases. Total 12 fungi viz., Aspergillus flavus, A. niger, Alternaria spp., Botryodiplodia theobromae, Colletotricum musae, Fusarium equiseti, F. moniliforme, F. oxysporum, F. solani, Mucor circinelloides, Penicillum spp. and Rhizopus stolonifer were isolated from diseased fruit samples. Pathogenicity test also fulfilled Koch's postulates.

Key words : Banana, Disease incidence, Post-harvest diseases, Fungal isolation

How to cite this paper: Pal, Aradhana, Singh, R.P., Singh, Pooja and Tripathi, N.N. (2017). Some studies on post-harvest pathogens of banana from Gorakhpur (U.P.). Asian J. Bio. Sci., 12 (2) : 79-86.DOI : 10.15740/HAS/AJBS/12.2/79-86. 